\title{
The Role of Teachers in Preventing Hoax Through School-Based Literacy Media Training at Tondano Senior High School
}

\author{
${ }^{1}$ Aldegonda Evangeline Pelealu* \\ History Education Department \\ Faculty of Social Science \\ Universitas Negeri Manado \\ Tondano, Indonesia \\ eviepelealu@gmail.com
}

\author{
${ }^{2}$ Eka Yuliana Rahman \\ History Education Department \\ Faculty of Social Science \\ Universitas Negeri Manado \\ Tondano, Indonesia \\ ekayulianarahman.@unima.ac.id
}

\begin{abstract}
This study aims to minimize the spread of hoax news through the participation of educational institutions, in the form of media literacy training for high schools' teachers at Tondano. This research is based on the negative influence of hoax news which later spread in the community. The media literacy approach is not only applied to students but also applies to educators who have the authority to provide positive knowledge and real values through the role of an educator. This research used the interview method with quantitative and qualitative approaches (Mix Method). Based on the theory of media literacy, the author elaborates on the skills of managing and overseeing the function of mass media as positive value knowledge for teachers. The result found the concept of media literacy training is in according to the experience and knowledge of teachers, also affirms that the educational institution is an important element of applying media literacy. The presence of the teacher to guide and teach students to become media consumers who understand their needs and able to think critically, questioning the motives behind television programs.
\end{abstract}

Keywords: Media Literacy, Media Education, Preventing Hoaxes

\section{INTRODUCTION}

Nowadays, the development of information technology is running significantly. The element of speed information delivery is considered one of the factors of the increasing spread of information through mass media. Since the development of media and technology goes very fast, it allows media users to be literate in information for they are not trapped in the wrong flow of information or hoaxes.

As mentioned by the Ministry of communication and informatics-based on their research results there are 800,000 sites in Indonesia included in the category of lying information spreaders, the statement explained that the internet had been mistakenly used by certain individuals for personal and group benefits by spreading negative content that caused unrest and mutual suspecting the community [1].

Currently, information or news is considered true is no longer easy to find. Survey reference [2] explains, from 1,146 respondents, $44.3 \%$ of them were exposed to false news every day and $17.2 \%$ got more than once a day. Even the main media is quite relied on by the public as a credible media that is sometimes exposed to hoaxes.
Not only by the main media but nowadays much false news also circulates through online media. The results of research conducted by reference [2] confirmed the channels are widely used in hoax distribution are websites, amounting to $34.90 \%$, message sharing applications such as (Whatsapp, Line, Telegram) are $62.80 \%$, while social media (Facebook, Twitter, Instagram) are the most used applications reaching $92.40 \%$ [3], [4].

Based on the research findings, it is deemed necessary to find a formulation to minimize the exposure to questionable information (hoaxes). At least through the active role of educational institutions. The world of education is a very potential scope to instill the values of honesty that are packaged in structured and measurable learning.

The author, in this case, offers a multi-role approach based on media literacy in high school level education units (SMA / K / MA). The media literacy approach is not only applied to students but also applies to educators who have the authority to provide positive knowledge and honesty values through the role of an educator (teacher). Why do teachers have to take part in the news (hoaxes)? Because educators or teachers are informants for their students. The teacher is the main source of student knowledge at school.

Based on the previous research and data presented, the author will elaborate on how the concept of developing school-based media literacy training is possible to be applied at the education level of High School, as a formula to counter hoax news. Given the reality, many people actively use the media in their daily lives but do not have the skills and knowledge of adequate media literacy.

Their access to the media is very high, but they are less able to use media for they access meaningfully, and sometimes even to have the opportunity to experience things is detrimental to themselves. In developed countries such as the United Kingdom, Canada (mainly Ontario), Australia, Finland, Denmark, Norway, the Netherlands, Sweden, France, and Switzerland, media literacy abilities or skills are taught formally through the school curriculum [5]. 


\section{RESEARCH METHODS}

This is qualitative research. According to reference [6] qualitative research is aimed to understand the phenomena about what is experienced by research subjects, for example, behavior, perception, motivation, action, etc. in a descriptive way in the form of words in a special natural context by utilizing various natural methods.

This type of research used is descriptive research. Descriptive research requires the author to explore in detail to explain the development of the concept of media literacybased training as one way to prevent the dissemination of hoax information at the level of the Secondary Education unit. Includes identifying training needs, information processing skills, honing critical thinking skills, tracking information sources, and the ethical use of information sources.

Based on the definition it can be concluded that the initial step of data analysis is gathering existing data, compiling in full, managing, and analyzing. In this research data collection uses interview techniques with informants who are considered potential.

\section{RESULT AND DISCUSSION}

Based on the results of interviews the authors submit a number of informants who work as teachers at SMA Negeri 1 Tondano, in general, they know the development of information technology is rapidly spreading along with the adverse effects of the media. They not only know but have been victims of the increasingly widespread hoaxes spread in almost all groups including High School Students at Tondano. Hoaxes had caught the attention of residents in North Sulawesi include information on the aftershocks and tsunamis that occurred in North Sulawesi in November 2019 ago, Hoaxes of fake eggs or plastic eggs to the latest hoax of a number of people infected with the Coronavirus (Covid19) in Manado. These three lies spread widely through social media (Facebook) and Whatsapp Group.

\section{Identify Training Needs for the Application of Media Literacy to Teachers}

Before elaborating more details regarding hoax prevention through the application of media literacy, an important issue that needs to be prepared is to identify the needs of media literacy training. The aim is to support the achievement of targets, namely the teacher's role in equipping students in understanding mass media content, to avoid being exposed to hoaxes. The following is the identification of needs during the application of media literacy in high schools, including:

1. Identify the socio-cultural background and the level of technology adaptation of the trainees.

2. Forming study groups or communities within the scope of teachers, students, and students' parents.

3. Determine effective training methods.

4. Provide debriefing in the form of the participation of teachers, parents, and the community regarding the importance of monitoring the source and content of information that will be consumed by middle school students in Tondano.

\section{Steps}

1. Investigate the social background and types of media most frequently used by teachers. At this stage, all teachers will describe the social background and type of media used. The aim is to identify sociologically the level of knowledge and mastery of digital technology.

2. Choice of training methods. The author facilitates it with creative methods. This method is emphasized the activities of creating or making works and reflecting on the work process and its' work [7].

This method allows participants in this case the teacher to interact and collaborate to find and solve problems.

Determination of the theme and material preparation. The choice of themes is certainly based on the needs of the trainees. Based on the results of interviews about $70 \%$ want material to have a correlation with the negative impact of mass media among teenagers. This finding was obtained from the experience of teachers having access to media and information sources, although they differed in duration and frequency in either watching television, reading newspapers, or connecting to the internet. The experience of consuming media as stated by [8] will ultimately shape knowledge about mass media. Based on interviews with a number of teachers they are known to have knowledge of the mass media especially they often observe especially broadcast media and online media that are locally based in Tondano and surrounding areas.

\section{Implementation}

In this case, teachers as trainees will be trained to understand the concept of media literacy education as developed by [5], [8], [9], [10]. From the results of research and experience in developing media literacy, they proposed a number of general topics to be trained namely knowledge of media literacy, analysis of media content, evaluation of mass media, and ways of producing messages for mass media. For the needs of high school teachers especially in Tondano. It is adjusted to the socio-cultural background of the teacher. Based on the results of interviews with informants, the authors found a number of topics developed into a training syllabus. Includes:

\section{Introduction to Media Literacy}

- Why is it important for media Literacy

- Various forms of mass media

- Mass media ownership

- The function of the media as a means of education

2. Analysis Fill in media messages

- Framing Media Techniques. How the media frame an event media analysis technique. How to find out the contents of the media based on the choice of title, news content, and field facts.

3. Hoaxes and threats in the world of education 
- Identify hoax news and how to prevent it

- The negative impact of the mass media

- Norm of digital society

These three media literacy topics will serve as guidelines for preparation at the high school student level. But before it is formulated into a curriculum the aspects of the material's compatibility will be examined with the psychology approach of high school students who are guided by the principles of pedagogy. Although the learner used the andragogy approach, in the learning process of media literacy, this does not mean ignoring the pedagogical approach. Moreover, between andragogy and pedagogy approaches as expressed by refence [11] are not two opposing or contradictory approaches, but rather are parallel.

Media literacy training is not only conducted in the classroom. But it will continue with the evaluation and monitoring process. The purpose of this evaluation is to assess the extent to which media literacy training is applied to minimize the exposure of hoax news among high school students at Tondano.

In the evaluation phase, the author will plan ongoing research on the results of its application after the training activities have been conducted.

\section{The Process of Continuous Independent Learning}

To discuss the preparation and implementation of media literacy training, it is also important to develop discussions based on the participants' independent learning experiences. In this way, the participant will involve, because discussed is what he experiences in real life. Such involvement will make the teacher as a trainee feel also as a source of learning.

The experience of the teacher consuming media is expected to be able to identify hoax news originating from the mass media information distribution especially television and social media (Facebook \& WhatsApp). Real problems experienced by the prospective participants can be used as cases that are studied in student activities, for the learning process takes place centered on the experiences of teachers according to environmental conditions and how they understand the media content to be learned. This experience-based approach is expected to identify problems and find solutions independently based on an understanding number of materials designed to help teachers understand hoax news in the community.

\section{Teacher and Parent Collaboration}

After following this training, the teacher is expected to become a consular media literacy for parents of students. Hopefully, the information can be reached directly by parents. As was done by the community concerned about the media in Yogyakarta. explained by the Children's Media Development Foundation [12]. The role of the teacher also contributes to providing guidance for students' parents. In this form, a resource needs to understand the problem accurately due to it must be able to convince parents that the mass media can cause serious problems and impacts on children if adequate arrangements and supervision are not made. If parents are not aware of this, it will be difficult to get them to supervise and regulate their children in using mass media.

The experience of media literacy training developed by the Children's Media Development Foundation (YPMA) provides a number of case studies on the impact of media in the form of imitation resulting in the death of children, it is very important to explain. For example, the SmackDown case which resulted in three children died. Also, the case of a child trapped by Naruto's headband in Semarang.

Likewise, hoax news targeting youth, for example recently a commissioner from an official state institution, the field of children protection of Indonesia, Sitti Hikmawaty, has caused public excitement. Through her comments she said, women can get pregnant if swimming with the opposite sex. Interestingly, hoax information like this turns out not only to be consumed by people with low levels of education but in fact, it is consumed by people with higher education levels and has the adequate economic capacity. Therefore, is important for teachers and parents to collaborate to provide the adequate and measurable understanding and supervision. But it should be accompanied by a set of knowledge about how the media and social media also produce hoaxes, at least questioning the motives for spreading fake news.

One of the efforts to combat hoaxes is to make educational institutions present to reduce the flow of mass media information. This training program is designed to contribute multi-parties to be integrated into the high school curriculum, according to reference [5] media literacy is considered a life skill that should be introduced earlier. In Indonesia, few schools apply literacy media or being a volunteer. In general, media literacy programs tend to be rated as new burdens for teachers who have been burdened by the curriculum system which is dense.

\section{CONCLUSION}

1. Media literacy training is only one of instrument. The role of the parties, teachers, parents, and the government is considered important to control the hoax.

2. The implementation of media literacy training is not only conducted in the classroom. But it will continue with the evaluation and monitoring process. The purpose of this evaluation is to assess the extent to which media literacy training is applied to minimize exposure hoax news among high school students at Tondano. In the evaluation phase, the author will plan ongoing research on the results of its application after the training activities are conducted. 


\section{ACKNOWLEDGMENT}

Thank you for Dean Faculty of Social Sciences for supporting this research.

\section{REFERENCES}

[1] Kominfo, 'Ada 800.000 Situs Penyebar Hoax di Indonesia', 2016. [Online]. Available: https://kominfo.go.id/content/detail/12008/ada800000-situs-penyebar-hoax-diindonesia/0/sorotan_media. [Accessed: 02-Mar2020].

[2] Mastel, 'Hasil Survey MASTEL Tentang Wabah HOAX Nasional', http://mastel.id/infografis-hasilsurvey-masteltentang-wabah-hoax-nasional/, 2017.

[3] A. B. Pratama, 'Ada 800 Ribu Situs Penyebar Hoax di Indonesia', 2016. [Online]. Available: https://www.cnnindonesia.com/teknologi/20161229 170130-185-182956/ada-800-ribu-situspenyebarhoax-di-indonesia/.

[4] C. Juditha, 'Hoax Communication Interactivity in Social Media and Anticipation (Interaksi Komunikasi Hoax di Media Sosial serta Antisipasinya)', Pekommas, vol. 3, no. 1, 2018.

[5] B. Guntarto, 'Tantangan dalam Kegiatan Literasi Media di Indonesia', Ultim. J. Ilmu Komun., vol. 8, no. 1, pp. 1-36, 2016.
[6] L. J. Moleong, Metodologi Penelitian Kualitatif. Bandung: Remaja Rosdakarya, 2011.

[7] D. Gauntlett, Creative explorations: New approaches to identities and audiences. Oxon: Routledge, 2007.

[8] D. Buckingham, Watching media learning: Making sense of media education. ERIC Clearinghouse, 1990.

[9] S. Art, Media Literacy: Key To Interprenting Media Massages. 1995.

[10] Y. Iriantara, 'Pengembangan Kurikulum Pelatihan Melek Media untuk Masyarakat', in Literasi Media di Indonesia, Yogyakarta: UII, 2011.

[11] M. S. et. a. Knowles, Andragogy in Action: Applying Modern Principles of Adult Learning. San Francisco: Jossey-Bass San Francisco, 1984.

[12] Yayasan Pengembangan Media Anak, Bagaimana mengajarkan anak Pendidikan Media: Buku pegangan untuk guru sekolah dasar. Jakarta: YPMA (Yayasan Pengembangan Media Anak), 2007. 